\title{
Antibacterial Activity of Plants Extracts against Methicillin-Resistant Staphylococcus aureus and Vancomycin-Resistant Enterococcus faecalis
}

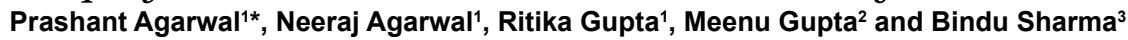

${ }^{1}$ Department of Biotechnology, Meerut Institute of Engineering and Technology, Meerut (MIET), 250005, India

${ }^{2}$ Department of Biotechnology Indian Institute of Technology, Roorkee (IITR), 247667, India

${ }^{3}$ Department of Biotechnology, Devanagri Post-Graduate College, Meerut, 250002, India

\begin{abstract}
The antibiotics resistant micro-organism has increased in past three decades. The Methicillin Resistant Staphylococcus aureus (M.R.S.A) and Vancomycin resistant Enterococcus faecalis (VRE) is a problematic in the field of medical science. This organism tends to cause serious infection in the burnt patients and mortality. MRSA is a major nosocomial pathogen. Thereby our study aims to control these micro-organisms using various plants extracts. Four plant species Ageratum conyzoides, Phyllanthus emblica, Camellia sinensis and Mentha longifolia were collected and subjected to ethanolic extraction. The ethanolic extracts were tested against clinically isolated multidrug resistance Enterococcus faecalis and Staphylococcus aureus. The ethanolic plants extracts were prepared at variable concentrations for Staphylococcus aureus and Enterococcus faecalis. In view of MRSA against clinically isolated Staphylococcus aureus and Enterococcus faecalis the concentration based analysis showed the zone of inhibition against the selected micro-organism in which Camellia sinensis was found potent against Staphylococcus aureus and Mentha Iongifolia against Enterococcus faecalis. In future after the detailed study it can be used as a potent biochemical drugs to overcome the infections caused by these organisms.
\end{abstract}

Keywords: MRSA (methicillin resistant Staphylococcus aureus); VRE (vancomycin resistant Enterococcus faecalis); MDR (multidrug resistant)

\section{Introduction}

The emergence and spread of multidrug resistant (MDR) bacterial pathogens have substantially threatened the current antibacterial therapy [1]. Even though pharmacological industries have produced a number of new antibiotics in the last three decades; resistance to these drugs by microorganisms has increased. In general, bacteria have the genetic ability to transmit and acquire resistance to drugs, which are utilized as therapeutic agents [2]. It has been estimated that between $60-90 \%$ of the populations of developing countries use traditional and botanical medicines almost exclusively and consider them to be a normal part of primary healthcare [3]. The most problematic bacteria include, but are not limited to, extended-spectrum $\beta$-lactamaseproducing Escherichia coli (ESBL-EC) and Klebsiella pneumoniae (ESBL-KP), carbapenem-resistant Enterobacteriaceae, Pseudomonas aeruginosa and Acinetobacter baumannii, hospital-acquired methicillin-resistant Staphylococcus aureus (MRSA) and vancomycin resistant Enterococcus (VRE) [4,5]. Thus, Infectious Diseases Society of America has recognized MRSA, VRE, ESBL-EP, ESBL-KP and Pseudomonas aeruginosa as notorious pathogens among the six major pathogens to which therapies with effective newer antimicrobials are urgently required [1,5]. Incidences of epidemics due to drug resistant microorganisms are now a common global problem posing enormous public health concerns [6]. The global emergence of multi drug resistant bacterial strains is increasingly limiting the effectiveness of current drugs and significantly causing treatment failure of infections [7]. Antimicrobial drug resistance is also of economic concern with impact on doctors, patients, health-care administrators, pharmaceutical companies and the public [8]. The non-availability and high cost of new generation antibiotics with limited effective span have resulted in increase in morbidity and mortality [9]. Therefore, there is a need to look for substances from other sources with proven antimicrobial activity. Consequently, this has led to the search for more effective antimicrobial agents among materials of plant origin, with the aim of discovering potentially useful active ingredients that can serve as source and template for the synthesis of new antimicrobial drugs $[10,11]$. A vast number of medicinal plants have been recognized as valuable resources of natural antimicrobial compounds [12]. Medicinal plant extracts offer considerable potential for the development of new agents effective against infections currently difficult to treat [6]. A wide range of phytochemicals present in plants are known to inhibit bacterial pathogens [13-15]. Many plant species have been used by the indigenous people of India as traditional medicines, including as treatments for infectious diseases. Successful determination of such biologically active compounds from plant material is largely dependent on the type of solvent used in the extraction procedure. Organic solvents such as ethanol, acetone, and methanol are often used to extract bioactive compounds [16]. Ethanol, however, is the most commonly used organic solvent by herbal medicine manufacturers because the finished products can be safely used internally by consumers of herbal extracts [17]. The aim of this study is to investigate the antibacterial properties of these extracts by exploring the activities against a collection of clinical isolates of MRSA and VRE.

*Corresponding author: Prashant Agarwal, Department of Biotechnology, Meerut Institute of Engineering and Technology, Meerut (MIET), 250005, India, Tel: 9760776126 E-mail: prashantagarwal2@gmail.com

Received August 09, 2016; Accepted August 28, 2016; Published September 09,2016

Citation: Agarwal P, Agarwal N, Gupta R, Gupta M, Sharma B (2016) Antibacteria Activity of Plants Extracts against Methicillin-Resistant Staphylococcus aureus and Vancomycin-Resistant Enterococcus faecalis. J Microb Biochem Technol 8: 404407. doi: 10.4172/1948-5948.1000316

Copyright: (c) 2016 Agarwal P, et al. This is an open-access article distributed under the terms of the Creative Commons Attribution License, which permits unrestricted use, distribution, and reproduction in any medium, provided the original author and source are credited. 


\section{Materials and Methods}

\section{Plant material}

Four plant samples were collected on the basis of traditional medicinal history of India from garden, local markets were studied. All the plant materials were further identified in the Department of Botany, D. N PG College Meerut, UP, India. Table 1 shows the botanical name, family, parts used and ethno-medicinal use of the plants under this study.

\section{Preparation of plant extracts}

The plant extracts were prepared with some modifications in the guidelines of [18]. Plant material was freeze-dried and milled to a coarse powder to extract sequentially with hot water and $80 \%$ ethanol. Each solvent was replaced three times with fresh solvents and was allowed to remain in contact with the plant materials for $48 \mathrm{hrs}$. The concentrated extract was centrifuged at $10,000 \times \mathrm{g}$ for $20 \mathrm{~min}$ at $20^{\circ} \mathrm{C}$. The supernatant was recovered, filter sterilized evaporated to dryness in vacuum and stored at $-70^{\circ} \mathrm{C}$.

\section{Microbial strains}

The MRSA strains used in this study were clinical isolates from patients presenting with symptoms of $S$. aureus-associated diseases. The isolates were identified as $S$. aureus according to colonial and microscopic morphology, positive catalysis, hemolysis and coagulase production. Strains of Enterococcus faecalis were isolated from patients suffering from nosocomial infections and identified on the basis of glucose fermentation without gas production, catalysis reaction, gamma hemolysis, reduction of litmus milk. Standard strains of Enterococcus faecalis (EFS) and Staphylococcus aureus (SAS) were done in the Department of Zoology, D. N PG College Meerut, UP, India. Standard strains and clinical isolates of MRSA and VRE.

\section{Assay for antibacterial activity}

After identification on selective medium all bacteria were grown on Nutrient Agar (Hi-Media M001A) and in Nutrient Broth (HiMedia M002) at $37^{\circ} \mathrm{C}$. Antimicrobial activity of the plant extracts was determined by the agar well diffusion method (Holder et al 1994), with modifications. $200 \mu \mathrm{L}$ of overnight NB culture were added to $15 \mathrm{ml}$ of molten MUELLER-HINTON Agar (Hi-Media M-173), mixed well, poured into a sterile PETRI dish and allowed to set. A sterile cork-borer ( $5 \mathrm{~mm}$ diameter) was used to make wells in the set agar. $25 \mu \mathrm{L}$ of plant extract, diluted 1:200 in sterile water, were added to triplicate wells and the plates were incubated overnight at $37^{\circ} \mathrm{C}$. Antibacterial activity was recorded as a zone of growth inhibition of greater than $5 \mathrm{~mm}$ around the well. All S. aureus isolates were tested for methicillin resistance. The disk diffusion method outlined by the National Committee for Clinical Laboratory Standards (NCCLS) was used with a $1 \mu \mathrm{g}$ oxacillin disk (Oxoid). Zone sizes were read after incubation at $35^{\circ} \mathrm{C}$ for $24 \mathrm{~h}$. Isolates with zone sizes $10 \mathrm{~mm}$ were considered methicillin resistant.

\section{Results and Discussion}

The plant extracts were prepared in different concentrations ranging from $0.2 \mathrm{mg} / \mathrm{ml}$ to $2.0 \mathrm{mg} / \mathrm{ml}$ using four different plants, the best results were obtained by enlisted concentration of plantsAgeratum conyzoides (Family- Asteraceae) $0.42 \mathrm{mg} / \mathrm{ml}$ and $1.52 \mathrm{mg} /$ $\mathrm{ml}$, Phayllanthus emblica (Family- Phyllanthacea) $0.75 \mathrm{mg} / \mathrm{ml}$ and 0.85 $\mathrm{mg} / \mathrm{ml}$, Camellia sinensis (Family- Theaceae) $0.85 \mathrm{mg} / \mathrm{ml}$ and $0.70 \mathrm{mg} /$ $\mathrm{ml}$ and Mentha longifolia (Family- Lamiaceae) $1.32 \mathrm{mg} / \mathrm{ml}$ and 0.55 $\mathrm{mg} / \mathrm{ml}$ for MRSA and VRE, respectively. As the bioactivity of plant extracts depends on the water and ethanol concentration used in the extraction process. Since ethanol is safe to ingest thereby it is most commonly used organic solvent to extract plants extracts which is used as potential therapeutic agent by human society. These extracts were tested for antimicrobial activity against gram positive bacteria Methicillin resistant Staphylococcus aureus (MRSA) isolated from burnt patients and gram positive bacteria Vancomycin Enterococcus faecalis (VRE) isolated from patients suffering from nosocomial infections. These micro-organisms are responsible for causing serious infection in the human body thus need to be treated. The antimicrobial activity was studied using zone of inhibition and zone $>5 \mathrm{~mm}$ was considered as positive result as shown in Table 2 and Figure 1 for MRSA and Table 3 and Figure 2 for VRE. It was observed that Camellia sinensis shows greater zone of inhibition against Methicillin resistant Staphylococcus aureus (MRSA), Mentha longifolia against Vancomycin Enterococcus faecalis (VRE), as compared to other plant's extracts.

\section{Conclusion}

Our studies have suggested that the plant Camellia sinensis is found potential antimicrobial agent against gram positive Methicillin resistant Staphylococcus aureus (MRSA) at $0.85 \mathrm{mg} / \mathrm{ml}$ concentration and plant Mentha longifolia against gram positive Vancomycin Enterococcus faecalis (VRE) at $0.55 \mathrm{mg} / \mathrm{ml}$ concentration. The activity of the Camellia sinensis and Mentha longifolia extracts provides preliminary scientific validation for the traditional medicinal use of this plant. Thus

\begin{tabular}{|c|c|c|c|c|}
\hline $\begin{array}{c}\text { Botanical } \\
\text { name }\end{array}$ & Family name & $\begin{array}{c}\text { Common } \\
\text { Name }\end{array}$ & Part Used & Ethnomedicinal Uses \\
\hline $\begin{array}{c}\text { Ageratum } \\
\text { conyzoides }\end{array}$ & Asteraceae & $\begin{array}{c}\text { Billygoat- } \\
\text { weed }\end{array}$ & Leaves & $\begin{array}{c}\text { Pneumonia [19], } \\
\text { bacteriocide, } \\
\text { antidysenteric [20], fever, } \\
\text { reumatism, headache } \\
\text { and colic [21,22] }\end{array}$ \\
\hline $\begin{array}{c}\text { Phyllanthus } \\
\text { emblica }\end{array}$ & Phyllanthaceae & Amla & Arial Part & $\begin{array}{c}\text { Antimicrobial [23], } \\
\text { antioxidant [24,25], } \\
\text { anti-inflammatory [26], } \\
\text { analgesic and antipyretic } \\
\text { [27,28], Adaptogenic [29], } \\
\text { hepatoprotective [30]. }\end{array}$ \\
\hline $\begin{array}{c}\text { Camellia } \\
\text { sinensis }\end{array}$ & Theaceae & $\begin{array}{c}\text { Green } \\
\text { Tea }\end{array}$ & Leaves & $\begin{array}{c}\text { Anticancer activity [31], } \\
\text { Cardiovascular Diseases } \\
\text { [32]. }\end{array}$ \\
\hline $\begin{array}{c}\text { Mentha } \\
\text { longifolia }\end{array}$ & Lamiaceae & $\begin{array}{c}\text { Horse } \\
\text { Mint }\end{array}$ & Arial Part & $\begin{array}{c}\text { Throat irritation, mouth } \\
\text { and sore throat [33]. }\end{array}$ \\
\hline
\end{tabular}

Table 1: Plant used in antimicrobial assay with their Ethno-medicinal uses.

\begin{tabular}{|c|c|c|c|c|c|}
\hline \multirow{2}{*}{ Plant Species } & \multicolumn{5}{|c|}{ Antibacterial activity against* } \\
\cline { 2 - 6 } & SA 1 & SA 2 & SA 3 & SA 4 & SAS \\
\hline Ageratum conyzoides & {$[6]$} & {$[6]$} & {$[6]$} & {$[6]$} & 6 \\
\hline Phyllanthus emblica & 6 & 5 & 6 & 6 & 6 \\
\hline Camellia sinensis & 6 & 7 & 8 & 8 & 10 \\
\hline Mentha longifolia & {$[6]$} & {$[6]$} & {$[6]$} & {$[6]$} & 7 \\
\hline $\begin{array}{c}\text { Penicillin G } \\
\text { (Reference Drug Control) }\end{array}$ & 12 & 12 & 12 & 12 & 12 \\
\hline
\end{tabular}

* Activity of plants extracts was determined from agar well diffusion assay. Numbers indicates zone of inhibition of test cultures around the wells. Each numbers was the average of quadruplets Zone of inhibition $>5 \mathrm{~mm}$ was considered as positive result. Numbers in the square brackets indicates incomplete inhibition (hampered growth but not complete abolition of growth) was observed within the specified zone. Concentrations of extracts were $0.425,0.75,0.85$ and $1.32 \mathrm{mg} / \mathrm{ml}$ for Ageratum conyzoides, Phyllanthus emblica, Camellia sinensis, Mentha longifolia, respectively, Penicillin $G$ was used as a reference control drug 


\section{Activity of plant extracts against MRSA isolates}

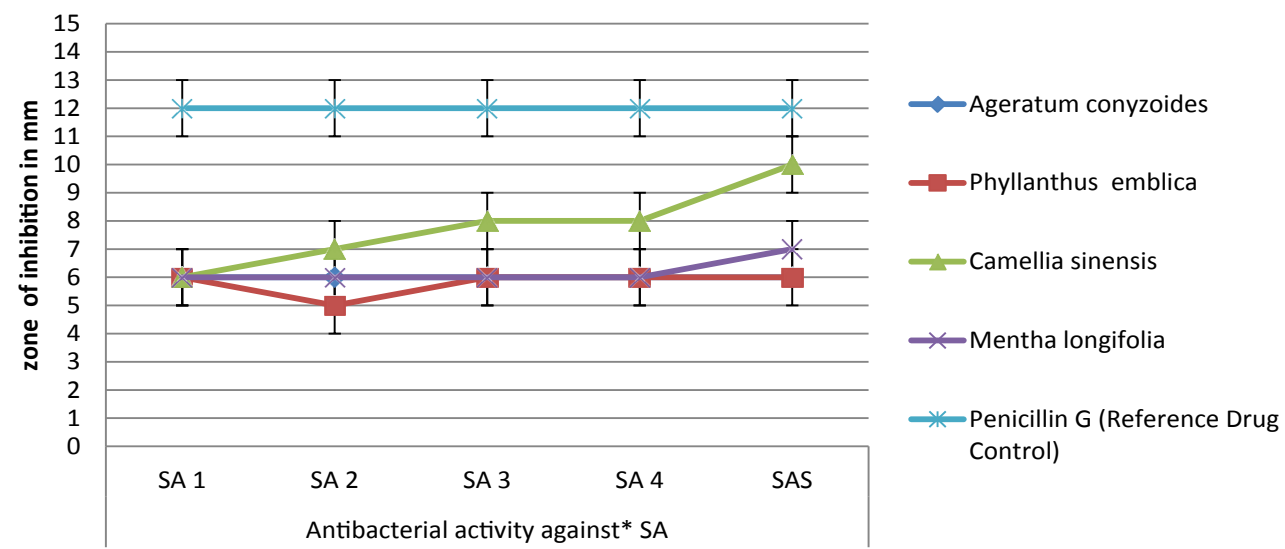

Figure 1: Graph showing the inhibition of MRSA against plant extracts denoted in Table 2.

\begin{tabular}{|c|c|c|c|c|c|}
\hline \multirow{2}{*}{ Plant Species } & \multicolumn{5}{|c|}{ Antibacterial activity against* } \\
\hline & \multicolumn{2}{|c|}{ EF 1} & \multirow{2}{*}{$\begin{array}{r}\text { EF } 3 \\
{[7]}\end{array}$} & EF 4 & EFS \\
\hline Ageratum conyzoides & [7] & [7] & & [7] & 7 \\
\hline Phyllanthus emblica & 6 & - & 5 & 5 & 6 \\
\hline Camellia sinensis & [6] & [6] & [6] & [6] & 7 \\
\hline Mentha longifolia & 7 & 7 & 9 & 8 & 10 \\
\hline Penicillin G (Reference Drug Control) & 12 & 12 & 12 & 12 & 12 \\
\hline
\end{tabular}

*Activity of plants extracts was determined from agar well diffusion assay. Numbers indicates zone of inhibition of test cultures around the wells. Each number was the average of quadruplets Zone of inhibition $>5 \mathrm{~mm}$ was considered as positive result. A negative symbol indicates no inhibition. Numbers in the square brackets indicates incomplete inhibition (hampered growth but not complete abolition of growth) was observed within the specified zone. Concentrations of extracts were $1.52,0.85,0.70$ and $0.55 \mathrm{mg} / \mathrm{ml}$ for Ageratum conyzoides, Phyllanthus emblica, Camellia sinensis, Mentha longifolia, respectively, Penicillin $G$ was used as a reference control drug

Table 3: Activity of plant extracts against VRE isolates.

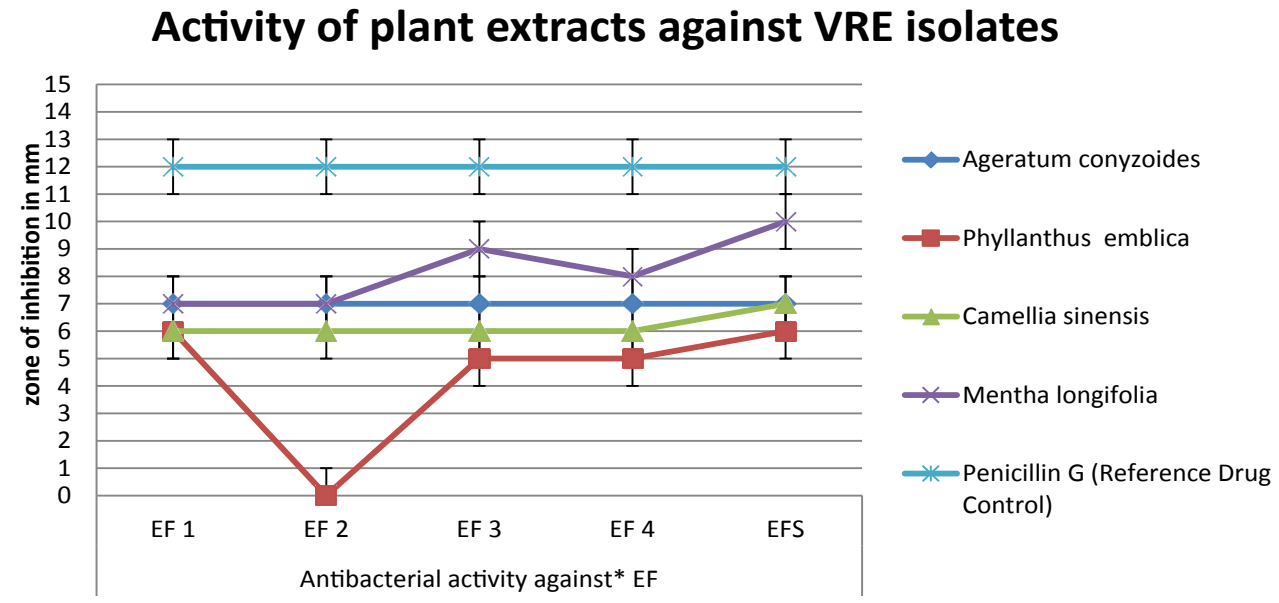

Figure 2: Graph showing the inhibition of VRE against plant extracts denoted in Table 3.

can serve as potential therapeutic agents however, the application of any compounds to medicine will require safety and toxicity issues to be addressed.

\section{Conflict of Interests}

The authors have no conflict of interests.

\section{References}

1. Boucher HW, Talbot GH, Bradley JS (2009) Bad bugs, no drugs: No ESKAPE!" An update from the Infectious Diseases Society of America, Clin Infect Dis 48: 1-12.

2. Cohen ML (1992) Epidemiology of drug resistance: Implications for a post antimicrobial era. Science 257: 1050-1055.

3. WHO (2002) Traditional Medicine Growing Needs and Potential - WHO Policy 
Citation: Agarwal P, Agarwal N, Gupta R, Gupta M, Sharma B (2016) Antibacterial Activity of Plants Extracts against Methicillin-Resistant Staphylococcus aureus and Vancomycin-Resistant Enterococcus faecalis. J Microb Biochem Technol 8: 404-407. doi: 10.4172/1948-5948.1000316

Perspectives on Medicines, No. 002, May, World Health Organization, Geneva, Switzerland.

4. Giamarellou H (2010) Multidrug-resistant Gram-negative bacteria: how to treat and for how long. Int J Antimicro Ag 36: 50-54.

5. Talbot GH, Bradley J, Edwards Jr JE, Gilbert D, Scheid M, et al (2006) Bad bugs need drugs: An update on the development pipeline from the Antimicrobial Availability Task Force of the Infectious Diseases Society of America. Clin Infect Dis 42: 657-668.

6. Iwu MM, Duncan AR, Okunji CO (1999) New antimicrobials of plant origin Perspectives on new crops and new uses. J. Janick (ed.), ASHS Press, Alexandria, VA.

7. Hancock REW, Kai Hilpert, Volkmer_enjert R, Walter T (2005) High-throughput generation of small anti-bacterial peptide with improved activity. Nat Biotechnol 23:1008-1012.

8. McGowan Jr JE (2001) Economic Impact of Antimicrobial Resistance. Emerging Infectious Diseases 7: 286-293.

9. Williams R (2000) Antimicrobial resistance a global threat. Essential Drug Monitor, 1: 28-29.

10. Pretorius JC, Magama S, Zietsman PC (2003) Growth inhibition of plant pathogenic bacteria and fungi by extracts from selected South African plant species. South African Journal of Botany 20: 188-192.

11. Moreillion P, Que YA, Glauser MP (2005) Staphylococcus aureus (Including Staphyloccal Toxic shock). In 'Principles and Practice of Infectious diseases $\left(6^{\text {th }}\right.$ edn),' Published by Churchill Livingstone Pennyslyvania 2: 2333- 2339.

12. Mahady GB (2005) Medicinal plants for the prevention and treatment of bacterial infections. Curr Pharm Des 11: 2405-2427.

13. Cowan MM (1999) Plant products as antimicrobial agents. Clin Microbiol Rev 12: $564-582$

14. Medina AL, Lucero ME, Holguin FO, Estell RE, Posakony JF, et al (2005) Composition and antimicrobial activity of Anemopsis californica leaf oil. J Agr Food Chem 53: 8694-8698.

15. Romero CD, Choph SE, Buck G, Martinez E, Garcia M, et al (2005) Antibacterial properties of common herbal remedies of the southwest. J Ethnopharmacol 99: 253-257.

16. Eloff JN (1998) Which extractant should be used for the screening and isolation of antimicrobial components from plants? J Ethnopharmacol 60: 1-8.

17. Low Dog T (2009) Smart talk on supplements and botanicals. Alternative and Complementary Therapies 15: 101-102.

18. Palombo EA, Semple SJ (2001) Antibacterial activity of traditional Australian medicinal plants. J Ethnopharmacol 77: 151-157.

19. Durodola JJ (1977) Antibacterial property of crude extracts from herbal wound healing remedy—Ageratum conyzoides. Planta Med 32: 388-390.

20. Borthakur N, Baruah AKS (1987) Search for precocenes in Ageratum conyzoides Linn. of North-East India. J Indian Chem Soc 64: 580-581.

21. Menut C, Sharma S, Luthra C (1993) Aromatic plants of tropical central Africa Part X-Chemical composition of essential oils of Ageratum houstonianum Mill. and Ageratum conyzoides L. from Cameroon. Flavour Fragrance J 8: 1-4.

22. Bioka D, Banyikwa FF, Choudhuri MA (1993) Analgesic effects of a crude extract of Ageratum conyzoides in the rat. Acta Hort 332: 171-176.

23. Ahmad I, Mehmood Z, Mohammad F (1998) Screening of some Indian medicinal plants for their antimicrobial properties. J Ethnopharmacol 62:183-193.

24. Chatterjee UR, Bandyopadhyay SS, Ghosh D, Ghosal PK, Ray B (2011) In vitro anti-oxidant activity, fluorescence quenching study and structural features of carbohydrate polymers from Phyllanthus emblica. Int J Biol Macromol 49: 637-642.

25. Sumitra M, Manikandan P, Gayathri VS, Mahendran P, Suguna L (2009) Emblica officinalis exerts wound healing action through up-regulation of collagen and extracellular signal-regulated kinases (ERK1/2). Wound Repair Regen 17: 99-107.

26. Golechha M, Bhatia J, Ojha S, Arya DS (2011) Hydroalcoholic extract of Emblica officinalis protects against kainic acid-induced status epilepticus in rats: Evidence for an antioxidant, anti-inflammatory, and neuroprotective intervention. Pharm Biol 49:1128-1136.

27. Mythilypriya R, Shanthi P, Sachdanandam P (2007) Analgesic, antipyretic and ulcerogenic properties of an indigenous formulation Kalpa amruthaa. Phytother Res 21:574-578.

28. Perianayagam JB, Sharma SK, Joseph A, Christina AJ (2004) Evaluation of antipyretic and analgesic activity of Emblica officinalis Gaertn. J Ethnopharmacol 95: 83-85.

29. Baliga MS, Meera S, Mathai B, Rai MP, Pawar V et al (2012) Scientific validation of the ethnomedicinal properties of the Ayurvedic drug Triphala: $A$ review. Chin J Integr Med 18:946-954.

30. Gulati RK, Agarwal S, Agrawal SS (1995) Hepatoprotective studies on Phyllanthus emblica Linn. and P. quercetin. Ind J Exp Biol 33: 261-268.

31. Smith DM, Dou QP (2001) Green tea polyphenol epigallocatechin inhibits DNA replication and consequently induces leukemia cell apoptosis. Int J Mol Med 27: 645-652.

32. Miura Y, Chiba T, Miura S, Tomita II, Umegaki K (2000) Green tea polyphenols (flavan 3-ols) prevent oxidative modification of low density lipoproteins: An ex vivo study in humans. J Nutritional Biochemistry 11: 216-222.

33. Al-Bayati FA (2009) Isolation and identification of antimicrobial compound from Mentha longifolia L. leaves grown wild in Iraq. Ann Clin Microbiol Antimicrob 8: 20 . 